\title{
A PRAGMATIC ANALYSIS OF THE SPEECH ACTUSED IN PULP FICTION MOVIE SCRIPT
}

\author{
N.G.P. Putra, D.P. Ramendra, G.A.P Suprianti \\ Pendidikan Bahasa Inggris \\ Universitas Pendidikan Ganesha, Singaraja, Indonesia \\ Email: \{khandeakito@gmail.com, putu.ramendra@undiksha.ac.id, gap.suprianti@undiksha.ac.id \}
}

\begin{abstract}
Abstrak
Komunikasi tidak hanya diterapkan di kehidupan nyata, tetapi juga diterapkan di media literatur seperti film sebagai sarana hiburan untuk menyampaikan makna ke penonton. Penulis mencoba menganalisa penggunaan tipe speech act; illocutionary act,yang diklasifikasian oleh Searle (1980) menjadi 5 tipe yaitu representative, directive, commissive, expressive dan declarative. Dan strategy dalam berkomunikasi seperti yang diusulkan oleh Mullany (2010), direct speech act dan indirect speech act yang digunakan untuk menyampaikan makna dalam bertutur antara penutur dan lawan bicara. Data dianalisis dengan cara mendeskripsikan data yang diajukan oleh Best dan Khan (2008). Penelitian menunjukan bahwa penggunaan illocutionary act lebih banyak terjadi pada directive act sedangkan tidak ada data yang ditemukan dalam pengucapan declarative act Kesimpulannya. beberapa ucapan mempunyai makna yang sesuai dan secara tidak langsung memiliki makna yang berbeda.
\end{abstract}

Kata kunci: speech act, illocutionary act, direct and indirect speech act.

\begin{abstract}
Communication is not only applied in real life, but also applied in media literature such as film as a means of entertainment to convey meaning to the audience. The author tries to analyze the use of speech act types; illocutionary act, which is classified by Searle (1980) into 5 types namely representative, directive, commissive, expressive and declarative. And communication strategies as proposed by Mullany (2010), direct speech act and indirect speech act that are used to convey meaning in speaking between the speaker and the interlocutor. Data were analyzed by describing the data submitted by Best and Khan (2008). Research shows that the use of the illocutionary act is more common in the directive act while no data is found in the pronunciation of the declarative act. In conclusion, some sayings have corresponding meanings and indirectly have different meanings.
\end{abstract}

Keywords: speech act. Illocutionary act, direct and speech act.

\section{INTRODUCTION}

Every person has their way to express their feeling and their mind. One of the way is by using language for communicating to each other. They can use both written or oral language and the only difference is only on the media used. In order to make communication successful, the ones who hear/read have to understand the person who speak/write. Thus the language goals is the hearer understand what the speaker utters when they have conversation or communication. It is common for people in making unstructured communication in certain situation and does not become a problem because the most important of communication is their speech can be understood and accepted by others. It is 
tin line with the Parker's argument (1986:12) that what people have to do in communication is how they use language to communicate rather than the way of language is structured internally. Yule (1996) says that in the effort to express and asserting him/herself, people do not only produce grammatical structure sentences but they also produce or show actions in that language. In real life, communication is divided into two types; verbal communication and nonverbal communication. Verbal communication is the way of communicating message by using words as element. Meanwhile verbal communication is the way of communication using hand gesture, body movements, facial expression, eye contact or physical appearance as element. They are used to interact each other between speaker and listener in certain conversation in which the speech act occurs at the time.

Speech act is the utterance which speaker says or speaker performs in every speech. Speech act performs when people make utterances such as apology, greeting, request, complaint, invitation, compliment, or refusal. One importance of studying speech act is to make people comprehend what message that is discovered in every utterance. Speech act is also decided by the language ability of speaker to convey the message in communication. Hence, the meaning of speech act can be understood clearly. Speech act also is a subdivision of pragmatics. According to Yule (1996), speech act is a study of how the speakers and hearers use language. Bach (1979) explains that an action in verbal communication has message in itself, so the communication is not only about language but also with action. In learning language, it closely would be related to two branches of language; pragmatics and semantics. But both branches concern on different side of language. Mullany (2010) cites that semantic is more concern on the literal meaning of language such as utterance, sentence and word, meanwhile pragmatic more is concern on the meaning of language in certain context such as conversation, dialogue, utterance, etc.

Meurers (2004) argues that pragmatics is the study which focuses on language in use and its integration of context. The communication is successful if the hearer understands what the speaker utters, in pragmatic the hearer also understand the context of utterance interpreted. Stalnaker (1972) as cited in Searle (1980) states that pragmatic is the study of the context of the linguistic act is performed. Meurers (2004) defines that pragmatic is the study which focuses on language in use and its integration of context. The main thing which is related to pragmatics is utterance in context which may build a new meaning in different context. Pragmatics is created in certain context or situation, the question where, when, why, how the situation around them (speaker \& hearer) can be drawn.

Nowadays the entertainment media such as movie is more advanced and have many aspects that can influence human's life, especially the use of language. Movie has contained the colorful language that have different meaning that some people do not even catch this. It is not only about the entertainment, while watching movie, people can also get the moral value, education and other value and even the social relations between actors, the dialogue or utterance they use and the linguistic elements in the movie. The phenomena of speech act also occur in movie. Real life and movie are the same reflection but in different form and it still needs human communication. The characters or actor apply speech act in movie to interpret their intended purpose to do something, action or express their feeling. Searle as cited in Seken (2015) classifies speech act into 3 types; locution act, illocution act and perlocution. Those types are classified based on the meaning of an utterance. Illocution act has more portion in speech act as Searle (1980) divides illocution act into 5 types. They are representatives, directives, commissives, expressive, and declaratives. Because these type of illocutions are often used in conversations, the writer focuses on Searle's theory in this research. In order to make the illocutionary act utterances have more impact to the hearer, Zhu (2010) stated that direct and indirect can be used as an emphasis of meaning of an utterance uttered by the speaker. For example, the sentence "Do you want to stand here all day?". This sentence is in form of interrogative sentence but this utterance is an indirect speech act. What the speaker intended to say to the hearer is to move away and go 
somewhere else and the speaker does not expect the answer yes or no from the hearer. The utterance can be changed to "Move out the way" is imperative sentence and a direct command to the hearer to move.

In that case, the researcher will focus on analyzing the type of illocutionary act based on Searle theory and the meaning of the utterance of the actors in a movie script entitled Pulp Fiction (1994). This movie was written and directed by Quentin Tarantino and chosen by writer as this movie is most popular movie at that time. The time setting was around 90s and the place was in Los Angeles. This movie is an action movie with very strong languages that some people may do not understand their meaning. Pulp Fiction movie is divided into 4 act which are nonlinear (the timeline is not placed in chronological order) but each act is connected to each other. There will be 2 characters analyzed in this movie script, namely Vincent Vega casted by John Travolta and Jules Winnfield casted by Samuel L. Jackson. The considerations of selecting these two characters to be identified is they have more portion in the script. For example, Vincent Vega and Jules Winnfield mostly appeared to have conversation on act 1, act 4 and Vincent Vega the only character appeared in act 2.

The other reason the writer uses this move is this movie was released in 1994 which mean in this year, the use of English was a bit different from today. The racial factor also makes this movie a bit confusing. Jules, in this movie is an african-american man who spoke grammatically incorrect but people still can grab the meaning. The job of those two characters, Vincent and Jules, were a hitman and gangster. They have unique way to speak. For example, one of the directive utterance said by English Dave: "Vincent Vega, our man in Amsterdam, git your ass on in here", In the movie itself, the context was in a bar and they met each other and English Dave gave direct order to Vincent Vega to come to him immediately. Those reasons make the writer curious about the intended meaning of this movie.

Based on the research background, here are the research objectives:

1) To identify what illocutionary acts are used by the main characters in Pulp Fiction movie script based on Searle classification?

2) To analyze the meaning of illocutionary act used by the main characters in Pulp Fiction movie script?

3) To identify What speech act strategy used in each illocutionary act uttered by main character in Pulp Fiction movie script?

\section{RESEARCH METHODOLOGY}

The research design used in this research was a descriptive qualitative. It was used to identify the use of illocutionary act and speech act strategy in Pulp Fiction movie script. To get the source of the data, the researcher did a document analysis to analyze the movie script itself and the dialogue.

\section{FINDINGS AND DISCUSSIONS}

As stated in previous chapter, this research contained three problems. The first one is what kind of illocutionary act used. The second one is what the meaning of each illocutionary 
act used. The last is what kind of speech act strategy used by the two main characters of Pulp Fiction movie script.

The first problem was answered by conducting the document analysis by Best and Khan (2008). The analysis found that there are 38 utterances found that uttered by Vincent Vega and Jules Winnfield. The utterance divided into 3 scenes out of 4 scenes because they only appeared on the first, second and fourth scene. First scene there are 11 utterances, meanwhile in second scene there are 10 utterances and in fourth scene there are 18 utterances.

The result found that directive act was uttered 19 times. Meanwhile expressive act was uttered 11 times. Commissive act was uttered 5 times. and representative act was uttered 4 times. In additional, the total amount of illocutionary act uttered in Pulp Fiction movie script are 39 utterances.

After identifying the problem above, the next step was to write the meaning of each illocutionary act type performed by two characters in Pulp Fiction movie script. In Representative, the use of this speech act type is rarely occurred in this script. The dialogue between Jules and Pumpkin (see appendix 1 no.32 scene IV), what happened between them was Jules in a middle of shop robbery in coffee shop while having breakfast. Pumpkin the robber, collected the walled and valuable goods from costumers and he finally came to Jules table. Jules put his wallet on the bag and Pumpkin notice the briefcase on the table that happened to be Jules'. While pointing gun at Jules, Pumpkin ordered him to open the briefcase but Jules refused. Pumpkin counted to three to open the briefcase and then Jules gave up and open the briefcase. According to Searle (1976), representative is an act to express or state what the speakers believe as a truth or not in the world. In this case, Jules admitted his lose from holding up the briefcase and he believe the briefcase was now Pumpkin's.

Representative as asserting act in dialogue between Wolf and Jules (see appendix 1 no.28 scene IV). The situation was Wolf inspected the Jules' car. Previously, Vincent (Jules' partner) accidentally shot someone in the backseat in the middle of highway, so they called wolf to help them to clean the mess. Wolf asked about the condition if the car had any engine issues and Jules answered with confident that there were no issues in his car. Jules' answer is an act of asserting. He asserted that the car was in good condition. Because he believed that during the accident, he drove the car without any issues. It was a truth as Jules believed it in first place and he can prove it.

The second speech act is directive. This is kind of speech act that the speakers use to get someone else to do something as the speakers intended in his utterance. The Language and Education Journal Undiksha | 34 
dialogue between Vincent and Jules in the middle of their mission (see appendix 1 no.4 scene I). As they walked down the corridor to find their target's room, they had a small talk about foot massage and their boss's wife. The conversation seemed to get intense and the forgot about their mission. Eventually, Jules reminded Vincent about their mission. They continued searching the room and they had a small talk again. Finally, they arrived in front of the target's door but they don't open it. Instead Vincent continued his talk and Jules just stood here quietly. And then, Jules said "That's an interesting point, but let's get into character". Jules' utterance is an act of directive act. He commanded Vincent to shut up and focus on their business. Even his utterance is not directly a command, Vincent understood what Jules tried to imply.

As seen in dialogue between Vincent and Jules (see appendix 1 no.9 scene 1), Jules found the briefcase what they looked for in the kitchen. While Vincent unlocking the briefcase, Jules had a conversation with Brett in other room. The briefcase opened and Vincent expression was a bit off while looking at the inside of the briefcase. Jules saw him and asked if this was the right briefcase by saying "Vincent, we happy?". Jules' utterance is a directive act of confirming. The phrase 'we happy?' is an expression if that was the right briefcase, they would happy with that fact. Otherwise they would not happy if they found out it was not the right briefcase. Vincent answered with utterance "We happy" with smileas that means it was the right briefcase.

In the dialogue between Vincent and Lance, Vincent used a direct command in his utterance. The situation was Vincent brought dying on drug overdose Mia (his boss' wife) to Lance's house (see appendix 1 no.20 scene II). Lance was a drug dealer and Vincent was hopping Lance could help him otherwise he would get in trouble. While Vincent accompanied Mia in living room, Lance searched for a medical book in his room. Vincent had no time and command Lance to quickly get the adrenaline injection for Mia. Vincent's command is an act of directive speech act. His utterance "Get your ass here, fuck the book!" is an direct command for Lance to forget the book he was search for, come quickly and get the injection for Mia. Lance understood what he meant in his utterance and act as his command.

The third type of speech act is commissive. This type of speech act used by speakers to commit themselves to some future action such as promising. The dialogue between Jules and Yolanda (see appendix 1 no.27 scene IV). She pointed her revolver gun to Jules as Jules pointed his gun to Pumpkin (Yolanda's boyfriend). Jules ordered Pumpkin to put their gun after counted to three. After Pumpkin put his gun, Yolanda yelled "Now let him go!" to Jules. His next dialogue is an expression of commissive act. Jules indirectly threatened Yolanda to stop yelling at him otherwise Pumpkin will get shot. He explained what happened 
if someone got nervous while holding gun, he would end up shooting someone. Yolanda knew what Jules' message in his utterance and stop yelling at him and stayed calm.

Meanwhile in a dialogue between Jules and Vincent, Vincent performed other form of commissive act. The situation was Jules asked Brett if he could take a bite of his burger (see appendix 1 no.6 scene I). The burger was tasted great and Jules offered some bite for Vincent. The next utterance by Vincent is an commissive act in form of refusing. He indirectly replied "I ain't hungry". It is clearly a declarative statement but what Vincent meant by his utterance was he refused Jules' offer because he was not hungry at that time. Jules understood what Vincent tried to imply and he continued eating the burger.

The last speech act type found in this movie script is expressive act. This kind of speech act used by speaker to express their psychological feeling such as feeling happy, angry, liking. A dialogue between Mia and Vincent is an act of complimenting (see appendix 1 no.16 scene 2). Complimenting is an act to congratulate or praise someone, their efforts and something politely. It is also associated with pleasant feeling. When they ordered their meal, Vincent surprised with Mia's beverage of choice which was a five-dollars milk shake. He thought this kind of drink just a regular milk shake and did not expected a five-dollars milk shake in such huge and fancy restaurant. As their orders came, Vincent asked Mia if he could have a sip of her five-dollars milk shake. Mia nodded and gave him her drink. After took a sip of her drink, Vincent surprise because this drink tasted better than regular milkshake he ever drank. His utterance "Goddamn! That's a pretty good milk shake!" is a direct compliment about the milk shake.Meanwhile 'goddman' is an expression of extreme displeasure, anger and surprise. But in this case, it expresses pleasure and surprise.

In an utterance when Vincent came in a restaurant, he wandered around and Mia called him to the table she reserved (see appendix 1 no.17 scene II). As they sat down, a waiter came and introduce himself as Buddy Holly. The waiter gave them menu book and began to write their order. After wrote down all of their order, the waiter took back the menu book and leave them to kitchen. Vincent said that he did not like Buddy Holly as a waiter. This is an expression of complaining as Vincent had an unpleasant feeling when he met Buddy Holly in the first place. His next line was "We shoulda sat in Marilyn Monroe's section". This utterance is an emphasis what he felt about Buddy Holly, instead he rather wanted Marilyn Monroe as his waitress.

The third problem was what speech act strategy used by two main character in Pulp Fiction movie script. In order to make illocutionary act have more impact to the hearers, the speakers use strategy in communication. Mulany (2010) stated that there are 2 strategies which are direct and indirect speech act. Direct speech act is commonly used by speakers to express what they intended in their utterances to the hearers so that the hearers do not have 
to observe the utterance specifically. But indirect speech act used by speakers to make more emphasis in their utterances to the hearers. Their intended meaning or action of implying meaning is beyond the literal sense.

This research found that direct speech strategy is the most used strategy used by Vincent Vega and Jules Winnfield. Direct speech act used in 22 utterances or 59\% and indirect speech act used in 17 utterances or $41 \%$.

The use of direct and indirect speech act hopefully make the hearers can catch the implicature of the speaker's utterance. Implicature means the meaning beyond the literal sense of what speakers stated. In dialogue between Jules and Pumpkin (see appendix 1 no.33 scene 4), the situation was Jules suddenly pointed his gun to Pumpkin and Yolanda (Pumpkin's girlfriend) jumped on table, started to yell at Jules to let him go. Jules uttered "Tell her to be cool! Say, be cool!", it is an order for Pumpkin to told Yolanda to calm down. Jules' utterance is a direct speech act. The sentence form of his utterance is imperative which mean ordering or commanding as seen in verb 'tell' followed by object 'her'.

On a scene when Vincent and Jules almost died because someone on bathroom suddenly showed up and fired a big revolver gun to them (see appendix 1 no.23 scene 4). But all of the 6 shots were missed and they shot back the man to death. Vincent furiously why Marvin the spy did not tell them that there was a man in a bathroom by saying "Why the hell didn't you tell us about that guy in bathroom? Slip your mind?". The speech act strategy used by Vincent in his utterance is direct speech act. His utterance is in form of interrogative sentence with emphasis of anger. Vincent expected Marvin to say yes or no, instead he used a non-verbal communication to Vincent which was nodding. Nodding means yes.

Meanwhile in dialogue between Jules and Vincent, the situation was after Jules and Vincent shot Brett to death (see appendix 1 no.22 scene 4). Vincent were about to leave but he saw a frightened man named Marvin sat in corner near the door. Jules ordered Marvin to leave but Vincent interfered by asking a question if they know each other. The strategy of speech act that Vincent used was indirect speech act. As seen in his utterance "Friend of youts?" is in form of interrogative sentence. Phrase 'friend of yours' is an assertion that a certain person and my interlocutor is friends. What Vincent tried to imply in his utterance was asked for that man name. Jules knew what the meaning of Vincent's utterance and he introduced them to another.

Other application of indirect speech strategy is on a dialogue between Jules and Yolanda. Jules pointed his gun to Pumpkin but Yolanda kept talking (see appendix 1 no.34 scene IV). His utterance "We ain't gonna do anything stupid are we?" is in form of interrogative sentence with speech act function of ordering. What Jules meant by his 
utterance was to order Yolanda to remain calm. If both of them did something stupid, their situation would get even worse.

\section{CONCLUSIONS AND SUGGESTIONS}

From the findings and discussions, it can be concluded that:

1. There were four types of speech act out of five performed by Vincent Vega and Jules Winnfield. the writer found that all Searle's illocutionary act are uttered in Pulp Fiction movie script. From this movie script, there are 4 representative utterances or $10.3 \%, 19$ directive utterances or $48.7 \%, 5$ commissives utterances or $12.8 \%$ and 11 expressive utterances or $28.8 \%$. out if 39 utterances in total.

2. In the findings, the writer found that Vincent Vega and Jules Winnfield used variety of speech act type namely representative, directive, commissive and expressive. Each speech act type has speech act function. In representative there are informing and admitting. Directive speech there are warning, commanding, commanding, confirming, insisting, asking, begging, suggesting and ordering. In expressive speech act there are complaining, protesting, refusing, promosog, complimenting, angry, praising and liking. Meanwhile commissive speech only has threatening.

3. The strategies of communication used by Vincent Vega and Jules Winnfield in this movie are direct and indirect speech act. This research found that there are 22 direct speech act or $59 \%$ and 17 indirect speech act or $41 \%$. The most used strategy is direct speech, because the illocutionary act directive is the most uttered than the other kind of speech act. Directive consist of commanding, ordering, suggesting etc. and Vincent Vega and Jules Winnfield used direct speech act as strategy in expressing their intended meaning behind their utterance.

Considering the conclusions mentioned above, some suggestions were recommended, as the following:

1. It is suggested for students. Studying speech act is not only for knowing the theory but also knowing its use in real life. Speech act has wide variety of study. The writer hopes that the readers get the basic idea of how the speech act works in context of movie, book and other literature media, even in real life circumstances.

2. For lecturers. Teaching speech act is important as it also applies to everyone real life circumstances. Understand how to communicate and how to absorb the meaning of variety of conversation in certain context either in verbal or non-verbal communication. 
Hopefully, lecturers in pragmatics field can provide more deep knowledge of pragmatic especially speech act.

3. For other researcher. Pragmatic has large scope of study besides speech act. Hopefully the other researcher can conduct a study about other pragmatic aspect and context such as real life circumstances.

\section{References}

Akinwotu, S. A. (2013). A speech act analysis of the acceptance of nomination speeches of chief obafemiawalowo and chief m. k. o. abiola. English Linguistics Research. 1. doi:10.5430/elr.v2n1p43

Altikriti, S. F. (2011). Speech act analysis to short story. Journal of Language Teaching and Research. 2. doi:10.4304/jtr.2.6.1374-1384.

Arani, S. S. (2012). A study of directive speech acts used by Iranian nursery school children: The impact of context on children's linguistic choices. International Journal of Applied Linguistics \& English Literature. 5. doi:10.7575/ijalel.v.1n.5p.163

Austin, J. L. (1962). How to do things with world. London: Oxford University Press.

Best, K.W., Kahn, J.V. (2006). Research in education: Tenth edition. New York: Pearson Education Inc.

Cohen, L., Manion, L., \& Morrison, K. (2007). Research methods in education. New York: Routledge.

Cresswell, J.W. (2009). Research design: Qualitative, quantitative and mixed method approach. Los Angeles: Sage Publications. Inc.

Denzin, N. K. (1970). The research act: $A$ theoretical introduction to sociological method. New Brunswick:Transaction Publisher

Jacobsen, R.R. (2010). The interpretation of indirect speech acts in relevance theory. Learn Danish. JoLIE 3/2010.

Levinson, S C. (1983). Pragmatics. Cambridge University Press: UK.

Meurers, D. (2004). Linguistics 201: pragmatic.

Mey, J. L. (1994). Pragmatics: An introduction. London: Basil Blackwell.

Mullany, L. and Stockwell, P. (2010). Introducing english language.Routledge: New York.

Muskannanfola, I. A. (2009). An analysis of illocutionary acts in victory speech and inaugural speech of barackobama .E- Journal, 39618.

Muttaqin, U. (2012). A speech acts analyis of zaid's utterances in moustaphaakkad's movie "the massage. English Language and Literature E-Journal, 11074766.

Parker, F. (1986). Linguistics for Non-Linguistics. London: Taylor \& Francis Ltd. 
Pulp fiction (1994) awards. (n.d.). Retrieved from http://www.imbd.com/title/tt0110912/awards

Pulp fiction awards. (n.d.). Retrieved from http://wiki.tarantino.info/index.php/Pulp Fiction/Awards

Searle, J. R., Keifer, F. and Bierwisch. M. (1980). Speech act theory \& pragmatic. Holland: D. Reidel Publishing Company.

Seken, I. K. (2015). Introduction to pragmatic: A course book for beginners. Yogyakarta: Grahallmu

Soengkono, N. (2013). Diktat sosiolinguistics. Tulungagung: Stain press.

Thomas, J. (1995). Meaning in interaction: An introduction to pragmatics. London and New York: Longman Group

Yule, G. (1996). Pragmatics. Oxford University Press: New York.

Zhu. D. (2016). Construction of Illocutionary Speech Meaning: Analyses of Conversational Narratives of a Chinese 60-year-old Woman. English Linguistics Research. doi:10.5430/elr.v5n4p54

Zumairoh, I. (2012). The analysis of speech acts used in "air force one" movie. English Language and Literature E-Journal. 